\title{
Integrating ICT into Teaching-learning Practices: Promise, Challenges and Future Directions of Higher Educational Institutes
}

\author{
Birhanu Moges Alemu \\ School of Educational Science and Technology of Teacher Education, Adama Science and Technology University, Ethiopia
}

Copyright (C) 2015Horizon Research Publishing All rights reserved.

\begin{abstract}
Education is a very socially oriented activity and quality education has traditionally been associated with strong teachers having high degrees of personal contact with students and technologies. Information and Communication Technologies (ICTs) have become commonplace entities in all aspects of life. The use of ICT has fundamentally changed the practices and procedures of nearly all forms of endeavour within business and governance. Within education, ICT has begun to have a presence but the impact has not been as extensive as in other fields. The use of ICT in education lends itself to more student-centred learning settings and often this creates some tensions for some instructors and students. But with the world moving rapidly into digital media and information, the integration of ICT into teaching-learning practices is becoming more and more important and this importance will continue to grow and develop in the $21^{\text {st }}$ century. This study aimed at exploring the process of integrating ICT into teaching-learning practices and its emerging challenges in Adama Science and Technology University. In this study, a mixed design (quantitative \& qualitative) in line of descriptive survey method was used. The sample population consisted of 203 respondents (188 instructors, 10 school deans and their vices and 5 department heads) from the five schools. Instruments were observation, individual interviews and questionnaires. The study argues the role of ICT in transforming teaching and learning and seeks to explore how this will impact on the way programs will be offered and delivered in the universities of the future. The analysis of data revealed that integrating ICT into teaching-learning is yet to be accomplished. The data revealed that the participants, both the instructors and students, have positive attitudes towards ICT and considerable knowledge and positive understanding of ICT and its potential in teaching and learning. However, the university fails to provide appropriate ICT-training courses for instructors to develop their technical ICT skills. Having said this, there are crucial examples of horizontal integration; that is, the instructors provide opportunities for the students to use ICT in meaningful contexts. The finding suggest that there is a relationship between the practitioners
\end{abstract}

' stages of concern and stages of adoption, which can be described as follows: the personal level of concern moves from the self-concerns' to =ask and impact-concerns', the personal adoption level is also likely to move from entry to invention. Although the finding reveal some crucial factors that has prevented the instructors and students from using ICT in teaching and learning, among these the institutional ones such as lack of proper access to ICT resources, overcrowded-classrooms, lack of technical and pedagogical support are more influential on the integration process. The researcher then recommended that, the ministry of education and Sample University should pass a bill at the national assembly on the use of effective ICT facilities in the educational system by provision of adequate fund, securing of ICT experts in university and ensuring that these facilities are monitored from time to time.

Keywords Challenges, ICT, Integration, Teaching-learning Practice, Quality Education, University

\section{Introduction and Rationale of the Study}

\subsection{Background of the Study}

This study examines how information and communication technology (ICT) has contributed in promoting educational development initiatives in Ethiopian Universities. Further, explore the process of integrating ICT into teaching-learning practices and its emerging challenges. This is an initial exploratory study that was accomplished through data analysis and critical literature review.

In this day and age, the role of technology in improving the lives of the people an enhancement of quality education cannot be underestimated. Most people, including minorities, more than ever before are now buying goods and services online, sending messages across the globe to loved ones, sending emails to donor agencies for support and receiving 
instant replies Barret,[4]; Becta ICT Research, [6]. It has been suggested that information and communication technologies (ICTs) can and do play a number of roles in education. These include providing a catalyst for rethinking teaching practice; developing the kind of graduates and citizens required in an information society; improving educational outcomes and enhancing and improving the quality of teaching and learning Betts, [7]; Cox, [11]. While all of these suggest the potential impact of ICTs in education in general and Ethiopia in particular, it is still difficult to demonstrate the potential of technologies in addressing specific teaching and learning problems faced by Ethiopian Universities.

Due to the potentially added value of ICT in education, all instructors and students should use ICT to support and enrich their teaching and learning activities. Education is unthinkable without the assistance of ICT. Using ICT in education cannot be avoided as it is a tool for the empowerment of instructors and students towards more effective and efficient education. ICT can be used as a research tool, problem-solving, creative and teaching and learning tool Akbulut et al., [1]:1; Kozma, [18]. ICTs have the potential to enhance teaching and learning through: enriching the course, improving delivery, extending methods of presenting information and offering new opportunities through the techniques that ICT makes possible Becta ICT Research, [5]:4. Instructors should have the opportunity to disseminate good practice via the Internet, access reliable facilities, resources and support on pedagogical issues and the latest curriculum developments Seyoum, [28]:44. Quick, easy and accurate reports and communication to and from the different sectors is possible via the Internet. ICTs can overcome instructor isolation by connecting them to colleagues, mentors, curriculum experts, and the global instructor community Carlson \& Gadio, [9]:119.

The integration of ICTs in teaching and learning is more likely if the tools and resources of the Internet, multimedia, and related technologies are seen as being integrally connected with literacy learning in the wider sense of learning as a matter of accessing information, communicating, and applying knowledge (Zhu, [34]). In other words, to the extent that they represent new tools, media, and functions of learning in the digital age, ICTs complement, extend, and transform the role of language-across-the-course in learning as the very basis of generic skills or competencies and applied knowledge as well as mere skill or content transmission. Thus, it might be argued that an across-the-course approach does not just complement and extend a more skills-focused and specialized use of ICT in formal education, but is a key to ICT integration in teaching and learning (Becta ICT Research, [6]; Jamieson-Proctor et al., [15].

In addition to promoting the learning of generic skills and applied knowledge orientations instead of mere skill or content transmission, an across-the-course approach is useful for recognizing and promoting the idea that to effectively integrate ICT in education instructors need to increasingly become designers rather than merely transmitters of learning Gibson, [13]. Such an approach naturally also extends a "new literacies" perspective of how language and literacy learning as formal study is more effective and relevant in various ways if grounded in the functions and aspects of informal everyday discourses and interactions outside the classroom Francis \& Ezeife, [12]; Wang \& Woo, [33].

Despite the undisputable importance of ICT in education Rodrigues, [26]), there clearly remain a number of issues that are not understood sufficiently Walsh, [32]. These include the relationships between technological tools available for learning delivery and their links with ethics and pedagogy/teaching-learning. Beside this the challenge of ICT integration is as much at the centre of a conflict between old and new pedagogies/teaching-learning as it is in terms of how educational values are alternately influenced by institutional imperatives for change and existing social contexts. Thus, the gap between older instructors and students, who embrace a global "wired" culture at home, is as significant as the cross-cultural clash between traditional educational practices and the imperative of progressive new theories of learning MoE, [21].

In Ethiopian universities some instructors have never had an opportunity to use computers for educational purposes nor have received any training in this regard. Although some instructors have recently been exposed to ICT through furthering their studies at higher learning institutions, it appears that the vast majority of instructors are unable to successfully integrate ICT into pedagogy/teaching-learning process (Ministry of Capacity Building, [22]). Further, ICT is available in many universities, but there is limited evidence that it has been integrated into the pedagogy/teaching-learning process Hare, [14]. According to Parker, Bianchi and Cheah [23]:15-18, integration is defined as "the process of totally integrating the use of ICT resources such as internet, e-mail, word processing, database, digital scanners, educational software package and the printer into the existing teaching-learning process through learning activities that address the course-area objectives". It appears that the primary reason for the lack of integration is that instructors' knowledge, skills and attitudes in Information Communication Technology (ICT) are inadequate, not only in terms of generic ICT competence, but specifically in integrating it into the pedagogy/teaching-learning process (Thorburn, [29]. Information and Communication Technology (ICT) generally relates to those technologies that are used for accessing, gathering, manipulating and presenting or communicating information. The technologies could include hardware; software applications; and connectivity.

Hence, instructors play a crucial professional role in ensuring that the integration of ICT into teaching and learning is educationally sound. They evaluate the appropriateness and effectiveness of available technologies, deciding when and how to use them with their students. Instructors integrating ICT into their pedagogies select appropriate learning activities, tools and resources to: (a) 
motivate and engage, (b) personalise learning, (c) engage with diversity to support inclusiveness, (d) develop ICT literacies, (e) establish communities of learning, and (f) assess progress and evaluate teaching. The effectiveness of integrating ICT into pedagogies/teaching-learning depends on high levels of interactivity amongst and between students and instructors, and between students and the technologies they use. To locate the place of ICT in teaching and learning, it needs to see the use of ICT as part of an instructor's pedagogy/teaching-learning. Further, a sophisticated understanding of that pedagogy/teaching-learning is required to ascertain the impact of ICT on practice. In particular, pedagogy/teaching-learning has to be seen in terms of several interrelated dimensions: (a) educational goals and purposes; (b) a view of learning; (c) a view of knowledge; (d) the learning and assessment activities required; (e) the roles and relationship among students and between the instructor and the student; and (f) the classroom discourse (Kovalchick \& Dawson, [17].

\subsection{Statement of the Problem}

In a baseline survey conducted by the Ministry of Education MoE, [21], it shown that most universities and institutions of higher education in Ethiopia have computers. However, these computers are few and, therefore, shared at a student-computer ratio of 10:1 in most cases. The study also showed that despite the presence of computers, most of the universities lack a network infrastructure and have limited connectivity. The instructors are yet to adopt ICT as a teaching-learning tool, and only a small number of students use computers and the Internet as a learning resource

Moreover, instructors in Adama Science and Technology University seem not to have been exposed to integrate ICT into teaching-learning process. The MoE [22] donated ICTs in universities that were mainly used for administrative purposes, thus many instructors may not have realised that computer technology is very useful for instructional purposes in education.

It also schools in the Adama Science and Technology University seem to have very few instructors that have access to ICT resources and other technology materials in integrating ICT into teaching-learning. The purpose of this study was to explorer the readiness and extent of instructors who participate in this study to integrate ICT into the teaching-learning process. Instructors integrate ICT into teaching and learning practices to engage students in new dimensions in: (a) exploring and experimenting, (b) thinking and working creatively, (c) reflecting and planning, (d) using feedback and self-assessment, (e) creating new knowledge, (f) communicating with others, and (g) working interactively with local and global learning communities.

Even though the technology is now almost ubiquitous effective use of ICT for teaching and learning in universities is not widespread. Some instructors have been able to integrate ICT into their teaching, and more importantly engage students in making use of ICT as part of the process of learning. The progress report of MoE[21] contains many positive examples of effective use of ICT by universities and individual instructors. However, there are still many barriers and impediments in the way of ICT becoming an integral part of teaching and learning. Regarding this the progress report of MoE [21] listed the following faults while using ICT: (a) ICT tasks are not related to objectives of lessons; (b) lack of guidance by instructors; (c) lack of knowledge about when to use and when not to use ICT; (d) lack of instructor skills and confidence; and(e) lack of appropriate intervention by instructors.

Therefore it is very essential to study the integration between pedagogy/teaching-learning, ethics and Information Communication Technology (ICT), which are the three important constructs for the development of an e-teaching and e-learning strategy. It is with this reason that the researcher becomes interested to asses issues and challenges in integrating ICT to pedagogy/teaching-learning and ethics in Adama Science and Technology University.

ICTs are ethically relevant uses of technology in education. In terms of supporting the learning experience ICT now finds application in content delivery, in course design and planning, in assessment and recording of achievement, and in communication between students and instructors, between students and between instructors. ICT use is, therefore, by now so closely interlinked with the educational process that it is hard to imagine a modern day educational system without it. "ICT-supported learning activity plan" provides an antidote of sorts to an add-on use of ICT in teachinglearning. This is insofar as the conventional generic structures of formal lesson-planning and syllabus design tend to reflect a view of learning as essentially a transmission of information or skills, as distinct from a dialogue between instructor and student or an interaction between students and the learning process (Cabanatan, [8]; Carlson \& Gadio, [9].

As various authors indicate, the instructors are the key element to the successful integration of ICT Asan, [3]:153; Carlson \& Gadio, [9]. The focus should shift to the instructor as the change agent for effective and sustained ICT integration. Instructors are in a position where they can make a difference and have a positive influence because instructors play a vital role in leading university reform, implementing innovations and making improvements. Quality teaching is widely acknowledged as the vital requirement of a successful university. Given the widespread assumption that high-quality teaching is an essential dimension of successful universities it seems to be imperative to have much more evidence about deans' and department heads influence on instructors' effective and sustainable ICT integration Kalake, [17]:53. However, research is restricted when it comes to the relationship of factors for the integration of ICT in universities in relationship with the specific role of the instructor.

The study is based on the following:

- Research findings confirmed that the instructor holds the critical position in the effective and sustainable 
development of ICT integration in universities Pelgrum, [24]:1-2.

- Instructors are the key element to successful ICT integration in classrooms. However, the focus should shift to the deans and department heads as the change agent to facilitate effective and sustained ICT integration. Leadership should facilitate the change process through being this "change agent' Vallance, [31]:290.

- Kalake [16]:53 states that: "Research on what enables instructors to effectively lead the implementation process and instructors' perceptions on the challenges and preferences of training was not found."

- A major theme that emerged from research on the implementation of ICT is the necessity for strong, committed leadership whose knowledge and commitment goes beyond the rhetoric of support. At the core of informed leadership is a person who has internalized the complexity of effective technology integration and who is able to exercises his or her influence to ensure that the various enabling factors are in place and being addressed Vallance, [31]:290.

- Various authors indicate that TPD in ICT won't be successful unless the instructor is vested in the process and drives the changing process Becta ICT Research, [5]:5; UNESCO, [30]; Walsh, [32]:5.

These above claims have led to the in-depth study on the influence of the instructors ICT integration into teaching and learning. MoE[22]:14 points out that very little is known about the characteristics of good instructor as there is insufficient recent and systematically-collected data on ICT instructor in education. It is important to explore, describe and explain the issues/challenges that contribute to instructors' use of technology; as well as of how they develop and spread effective ICT practice in the teaching environment through.

There is, in other words, a widespread belief that ICTs have an important role to play in changing and modernising educational systems and ways of learning. There is, however, little scientific evidence of the concrete contributions of ICTs to the learning domain, despite the efforts of the last decades. Hence, there is a need to bring evidence together on the impact of ICT on education and training in Ethiopian Universities. This is the objective of this working study. Currently there seems to be little interest in the exploration of the integration of teaching-learning and ICT. ICT are timely issues of interest but the majority of research in the area is narrow in its scope. The research question was formulated in line of the identification of research problems lead to the realisation that there is insufficient knowledge on the issues/challenges regarding instructors' professional development in ICT integration in universities. The following aspects guide the identification of the knowledge gap regarding instructors' professional development in ICT integration that lead to the research questions of this study: The MoE[4] policy document on e-Education indicates that ICT has to be integrated effectively into education to enhance the quality of teaching and learning. Hence the current study aimed to fill this gap and find solutions for the following research questions:

1. To what extent instructors integrate ICT to pedagogy/teaching-learning and ethics in instructional process?

2. What issues and challenges (materials, trainings, attitudes, support, and classroom conditions) affect the use of ICT in universities teaching- learning process?

3. What ICT resources (Internet, E-mail, word processing, databases, spread sheets, digital scanners, and education software package and computer printer) knowledge, attitudes and skills do the selected instructors have?

\subsection{Objectives of the Study}

The main objective of this study was to explore the integration of teaching-learning and Information Communication Technology (ICT), and surveying the issues and challenges affecting its implementation in universities, and to identify the impact that they have on each other. Hence, specifically, the objectives of this study were:

- to improve the competencies of instructors, through both pre-service and in-service education, in integrating/infusing ICTs as pedagogical tools and educational resources to facilitate student learning by minimizing factors hindering integration of ICT into teaching-learning practices;

- to identify Adama University instructors in ICT use in different teaching- learning environments;

- to put into operation university online instructors resource base and offline network of Adama Science and Technology University to share instructor-developed educational courseware and innovative practices.

\subsection{Significance of the Study}

The findings of this study would provide important information about the integration of ICT into teaching-learning process thus; they too are benefited from findings of the present study.

Therefore, the outcome of this study might help Ministry of Education, Adama Science and Technology University, school deans and department heads, instructors, students, and other concerned organs in universities to design preventive, intervention and rehabilitative measures regarding the integration of ICT into teaching and learning, and issues and challenges affecting its uses. Further, the researcher believes, this study has the following significances: 
- $\quad$ it can provide policy makers and educational officials at university levels with the information about the integration of ICT into teaching and learning practices;

- $\quad$ it may help instructors to improve their methods of instructional process by minimizing factor hindering integration of ICT into teaching-learning practices;

- $\quad$ it may help school deans and educational department heads to make the necessary follow up with regarding the integration of ICT into teaching and learning process;

- $\quad$ it may also initiate, encourage and serve as a steppingstone for further and more extensive research in ICT integration into pedagogy/teaching-learning.

\subsection{Delimitation of the Study}

The researcher believes that, it would be better to examine the extent of integration of ICT into teaching-learning practices of instructors in all universities across the country. Most reliable and valid information may be found if one could do so. However, due to constraints of time, financial and materials, as well as to make study more manageable and to complete the study within the available time the dimension of this study is confined to Adama Science and Technology University.

\section{Research Design and Methodology}

\subsection{Research Design}

The major components of this section are the methodology, source of data, the sampling techniques, instruments and procedures of data collection and method of data analysis.

This study aimed at exploring the integration of Information Communication Technology (ICT) into teaching-learning process, as important constructs for the development of an e-teaching and e-learning strategy.

The study is a mixed approach (quantitative and qualitative) study that focuses in a case of Adama Science and Technology University that researcher work in it. The researcher selected descriptive survey method to assess instructors' experiences in integrating ICT into teaching-learning process. This methods of study is also relevant together detailed descriptions of the existing condition and current practices of an educational phenomenon. According to Merriam cited in Creswell [10]:12 a descriptive study is "a study in which the researcher explores entity or phenomenon bounded by time and activity and collects detailed information by using a variety of data collecting procedures during a sustained period of time". Data will be collected from the instructors, deans and department heads at the selected school by means of: Questionnaires, interviews and observations.

\subsection{Sample Population and Sampling Techniques}

The respondents included in this study were university instructors, department heads, and school deans and vice deans selected from the five schools of Adama Science and Technology University, thus, four from the main campus (Adama), and the remaining one from Assela. And one-third of instructors from each sample schools were selected randomly. The total number of participants was -- i.e., 188 instructors, 10 school deans and their vices and 5 departments head, a total of 203. Thus, instructors, education department heads, school deans and their vices from the sample university were taken as sample of the study.

\subsection{Instruments}

This particular study made use of a number of data collection techniques. They were observation, individual interviews and questionnaires.

Questionnaires: The questionnaire was given to one-third of the total number of instructors in Sample University, which randomly selected participants in order for them to express their knowledge, opinions, attitudes and preferences about ICT. Instructors was given questions which will establish how much of ICT skills these they have and how they use ICT for teaching-learning. According to McCain [19], a structured questionnaire is an instrument with questions or statements to which respondents must react. The questionnaire was structured and unstructured that was closed and open questions. Instructors were asked to complete a questionnaire that focuses on: Their access to computers at university; How often do they use ICT resources (Internet, E-mail, scanner \& etc.)? What they think about ICT integration into teaching-learning? What is their competency level of ICT? What ICT skills are they interested in developing further teaching and learning? And how they feel ICT integration for pedagogy/teaching-learning?

Interviews: During the interviews, the researcher was verbally asking questions for individuals to answer verbally with an aim of gathering some information from the person being interviewed. The broad aims of the interview schedule were to explore: Teachers' perceptions of the relative successes, problems and challenges of working with integration of ICT into teaching-learning; change over the period of the study in teachers' approach to incorporating the use of ICT in their practice and how this relates to student learning; change over time in teachers' views about ICT in teaching and learning; and Teachers' views about the processes they experienced during the study.

Observations: In this research study, data was collected by recognized and noting the instructor's behavior and attitude towards the use of ICT resources. This observation was employed as a method of data collection to provide an accurate description of how instructors feel about ICT integration into teaching-learning process. The data that researcher was gather during observation was assist him, as a researcher to interpret the findings that are genuine since the researcher was not rely on the willingness and the ability of respondents to report data accurately. 


\subsection{Methods of Data Analysis}

The data collected through different instruments was organized, presented in tables and graphs, and then analyzed statically using such statistical methods percentages, means, standard deviation, t-test and $\mathrm{Ch}$-square. Tables and graphs were generated from the questionnaire, results, so that the essence of the interpreted information obtained can be presented systematically. Finally the results of analysis were interpreted to answer the basic research questions.

\section{Data Analysis and Presentation}

In chapter 2, the research design and methodology was explained. A descriptive survey design method was used. The chapter presents the findings on the extent at which instructors integrate ICT into teaching-learning and identify factors that affect the integration of ICT. This includes the extent at which the instructors integrate ICT into teaching-learning practice, using ICT resources for teaching and learning at the sample university, instructors' confidence in using ICT, training for ICT integration and obstacles to do not use ICT resources in the teaching-leaning activities.

\subsection{Instructors' Knowledge and Skills of Basic ICT Resources}

This section attempts to analyze and to present the collected data in response to the leading questions which were raised in the introduction.

As it can be observed from the above Table 1, the majority $(51.2 \% \& 48.1 \%)$ of instructors of the School of Business and Engineering respectively and $43.8 \%$ of instructors of the School of both Health and Humanity and Natural Science) of respondents responded that there is a good computer access in their schools. Only 52\% from instructors of the School of School of Educational Science\& Technology of Teachers Education responded that the computer access is very good. This is also shown by the mean values of responses of instructors of the sample schools. The grand mean, 2.99 of the responses in Table1, show that the computer access in different schools of Adama Science and Technology
University is good. In line to this, Seyoum [28] states that universities that have good ICT resources and utilize them well have better standards than universities where good ICT resources were not well used. The use of ICT resources by university-instructors is still very rare and very few instructors have their students use ICT resources frequently Seyoum, [28]. Computer access is one of the major factors which influence the realization of teaching-learning processes at the university level. In order to get sufficient and reliable information about the actual computer access the surveyed university's instructors, department heads and school deans were involved in this study.

The question that comes to the fore is that despite the availability and access of technology tools to the instructors and their preference for instructional technology, why were most of them still not using the various technology tools available to them to make their teaching more effective. There was found to be no significant relationship between the pedagogy followed and the effectiveness of pedagogy. This means that there could be certain other factors which limit the adoption of the instructional technology for teaching in spite of the fact that the instructors were convinced about the benefit of instructional technology. Could there be certain factors like age of the instructors, academic background, and the age of the university.

The Adama Science and Technology University has ICT classroom fitted with a few networked students' workstations, an instructor computer, a server and other technology such as a printer, and video conference set which is all operated by a satellite dishes. The Adama Science and Technology University ICT laboratory has access to the Internet and e-mail which are the components of ICT resources required for integrating ICT into teaching-learning classroom practices. Further, the Adama Science and Technology University ICT laboratory is earmarked for the use Internet and e-mail by instructors, students and the community members. Even though, the ICT laboratory in this university has no timetable for all department-learning allocating specific period for the integration of ICT in learning. Instructors are not allotted to do their ICT lesson preparations and administrative tasks.

Table1. Computer access in sample schools of Adama Science and Technology University

\begin{tabular}{|c|c|c|c|c|c|c|c|c|c|}
\hline \multirow{2}{*}{ Schools } & \multicolumn{2}{|c|}{ Non-extent $(1)$} & \multicolumn{2}{|c|}{ Fair(2) } & \multicolumn{2}{|c|}{ Good(3) } & \multicolumn{2}{|c|}{ Very good(4) } & \multirow{2}{*}{ Mean } \\
\hline & $\mathrm{f}$ & $\%$ & $f$ & $\%$ & $\mathrm{f}$ & $\%$ & $\mathrm{f}$ & $\%$ & \\
\hline School of Business & 2 & 4.9 & 6 & 14.6 & 21 & 51.2 & 12 & 29.3 & 3.05 \\
\hline School of Engineering & 3 & 5.6 & 8 & 14.8 & 29 & 48.1 & 17 & 31.5 & 3.06 \\
\hline School of Health & 1 & 3.1 & 12 & 37.5 & 14 & 43.8 & 5 & 15.6 & 2.71 \\
\hline $\begin{array}{c}\text { School of Humanity andNatural } \\
\text { Science }\end{array}$ & 2 & 4.2 & 17 & 35.4 & 21 & 43.8 & 8 & 16.7 & 2.73 \\
\hline $\begin{array}{l}\text { School of Educational Science\& } \\
\text { Technology of Teachers Education }\end{array}$ & 1 & 4 & 1 & 4 & 10 & 40 & 13 & 52 & 3.40 \\
\hline Grand mean & & & & & 2.9 & & & & \\
\hline
\end{tabular}


From this study, it appears that there are a few ICT integrations into teaching-learning in Adama Science and Technology University; that is e-learning in small number of courses are applied. The reason for this assumption is that throughout the observational period, there has never been a single instructor who is using the computer laboratory for teaching-learning practice rather the students are using computer for different purposes which is not related to teaching-learning process as such.

As can be seen from columns of Table 2, above the majority $140(69 \%)$ of instructor respondents are using computer in their homes. Only few 63(31.5\%) instructor respondents are not using computer in their homes. Interestingly it was found that in spite of the instructors feeling that the use of instructional technology tools was beneficial for students, there was found to be no significant relationship between the pedagogy followed and perceived usefulness of instructional technology tools.

Table 2.Use of computer at home

\begin{tabular}{|c|c|c|c|c|}
\hline \multirow{2}{*}{ Schools } & \multicolumn{2}{|c|}{ Yes } & \multicolumn{2}{c|}{ No } \\
\cline { 2 - 5 } & $\mathrm{f}$ & $\%$ & $\mathrm{f}$ & $\%$ \\
\hline School of Business & 28 & 13.8 & 13 & 6.4 \\
\hline School of Engineering & 39 & 19.2 & 18 & 8.9 \\
\hline School of Health & 19 & 9.4 & 13 & 6.4 \\
\hline School of Humanity and Natural Science & 33 & 16.3 & 15 & 6.9 \\
\hline $\begin{array}{c}\text { School of Educational Science\& } \\
\text { Technology of Teachers Education }\end{array}$ & 21 & 10.3 & 4 & 2 \\
\hline Total & 140 & 69 & 63 & 31 \\
\hline
\end{tabular}

As Table 3, shows that the instructors of the surveyed departments are using ICT resources (Internet, E-mail, Word- processing, Databases, Spreadsheets, Digital scanners, Educational Software package and Computer printer,) which are very important to integrate ICT to the teaching- learning practices. As it has been seen in columns of this table most $(31.5 \%)$ of instructor respondents are using Word- processing daily, however more than this percent of instructors $(45.5 \%)$ are using this computer resource weekly. The resource used daily by most (24\%) instructors next to Word- processing is Computer printer. The remaining computer resources are used daily only by few respondents.

The Table 3, indicates that more than a halve of respondents are using Internet (53.5\%) and Computer printer $(56.0 \%)$ Weekly and less than $18 \%$ of respondents are using each of the remaining (E-mail-9.5\%, Databases - 17\%), Spreadsheets $-10 \%$, Digital scanners - $10.5 \%$, Educational Software package - 17.5\%) resources weekly. Out of these resources two (E-mail $-52.0 \%$ and, Educational Software package $-64.5 \%$ ) are used by more than $50 \%$ of the respondents monthly and the other three (Databases- 74\%, Spreadsheets- $73 \%$, and Digital scanners- $72.5 \%$ ) and the remaining resources (Internet -14\%, E-mail -27\%, Wordprocessing $-11 \%$ and Educational Software package - 12 and Computer printer(14\%)\% are never used by the majority (more than $72 \%$ ) and more than $10 \%$ of the respondents respectively.

In general the instructor respondents of the surveyed schools are using basic ICT resources to integrate teachinglearning process. However, below $50 \%$ of instructors are using the resources in their daily teaching activities. Only Internet $(53.5 \%)$ and Computer printer $(56.0 \%)$ are used weekly, and E-mail $(52.0 \%)$ and Educational Software package $(64.5 \%)$ are even used monthly by more than $50 \%$ of respondents. There are also computer resources that are not used at all by different instructors particularly Databases, Spreadsheets and Digital scanners are never used by $145(72.5 \%)$ of respondents in their teaching-learning practices. The reasons given by most respondent instructors for not using the above stated ICT resources include the following: lack of skills, training, pedagogical support, technical support, time, instructors reserved attitudes and not accessible when needed.

Table 3. Frequency of using basic ICT resources

\begin{tabular}{|c|c|c|c|c|c|c|c|c|c|}
\hline \multirow{2}{*}{ ICT resources } & \multicolumn{2}{|c|}{ Daily(4) } & \multicolumn{2}{|c|}{ Weekly(3) } & \multicolumn{2}{|c|}{ Monthly(2) } & \multicolumn{2}{|c|}{ Never(1) } & \multirow{2}{*}{ Mean } \\
\hline & $\mathrm{f}$ & $\%$ & $\mathrm{f}$ & $\%$ & $\mathrm{f}$ & $\%$ & $\mathrm{f}$ & $\%$ & \\
\hline Internet & 36 & 18 & 107 & 53.5 & 29 & 14.5 & 28 & 14 & 2.76 \\
\hline E-mail & 23 & 11.5 & 19 & 9.5 & 104 & 52.0 & 54 & 27 & 2.06 \\
\hline Word- processing & 63 & 31.5 & 91 & 45.5 & 24 & 12 & 22 & 11 & 2.98 \\
\hline Databases & 8 & 4 & 20 & 17 & 24 & 15 & 148 & 74 & 1.12 \\
\hline Spreadsheets & 5 & 7 & 20 & 10 & 26 & 13 & 146 & 73 & 1.39 \\
\hline Digital scanners & 2 & 3 & 9 & 10.5 & 44 & 22 & 145 & 72.5 & 1.34 \\
\hline Educational software package & 12 & 6 & 35 & 17.5 & 129 & 64.5 & 24 & 12 & 2.18 \\
\hline Computer printer. & 48 & 24 & 112 & 56.0 & 12 & 6 & 28 & 14 & 2.90 \\
\hline Grand mean & & & & & 2.0 & & & & \\
\hline
\end{tabular}


Table 4. ICT competency of the instructor respondents

\begin{tabular}{|c|c|c|c|c|c|c|c|c|c|}
\hline \multirow{2}{*}{ Schools } & \multicolumn{2}{|c|}{ Unknown(1) } & \multicolumn{2}{|c|}{ Not competent (2) } & \multicolumn{2}{|c|}{ Competent (3) } & \multicolumn{2}{|c|}{ Very-competent(4) } & \multirow{2}{*}{ Mean } \\
\hline & $\mathrm{f}$ & $\%$ & $\mathrm{f}$ & $\%$ & $\mathrm{f}$ & $\%$ & $\mathrm{f}$ & $\%$ & \\
\hline School of Business & 6 & 14.6 & 5 & 12.2 & 22 & 53.7 & 8 & 19.5 & 2.78 \\
\hline School of Engineering & 14 & 24.2 & 26 & 44.6 & 16 & 29.6 & 1 & 1.9 & 2.09 \\
\hline School of Health & 5 & 15.6 & 13 & 40.6 & 12 & 37.5 & 2 & 6.3 & 2.34 \\
\hline $\begin{array}{l}\text { School of Humanity and } \\
\text { Natural Science }\end{array}$ & 3 & 6.3 & 14 & 29.2 & 30 & 62.5 & 1 & 2.1 & 2.60 \\
\hline $\begin{array}{c}\text { School of Educational } \\
\text { Science\& Technology of } \\
\text { Teachers Education } \\
\end{array}$ & 4 & 16 & 4 & 16 & 14 & 56 & 3 & 12 & 3.04 \\
\hline Grand mean & \multicolumn{9}{|c|}{2.57} \\
\hline
\end{tabular}

To sum up the grand mean (2.09) in the above Table 3, shows that most of the computer resources are used by the majority of instructor respondents in the sample University. This implies that most of instructors in different schools of Adama Science and Technology University have knowledge and skills of basic ICT resources. Technology has the capacity to promote and encourage the transformation of education from a very teacher directed enterprise to one which supports more student-centred models. Evidence ofthis today is manifested in: The proliferation of capability, competency and outcomes focused curricula; moves towards problem-based learning; increased use of the Web as an information source, Internet users are able to choose the experts from whom they will learn. The use of ICT in educational settings, by itself acts as a catalyst for change in this domain. ICTs by their very nature are tools that encourage and support independent learning. Students using ICTs for learning purposes become immersed in the process of learning and as more and more students use computers as information sources and cognitive tools (Phelps, Graham \& Kerr, 2004), the influence of the technology on supporting how students learn will continue to increase.

Table 4, above indicates that $(53.7 \%, 29.6 \%, 37.5 \%, 62.5$, \& $56 \%$ ) of instructors from the school of Business, Engineering, Health, Humanity and Natural Science, and School of Educational Science\& Technology of Teachers Education) of instructor respondents are respectively competent in ICT skills. Whereas, $(12.2 \%, 44 \% \%$, 40.6\%, $29.2 \% \& 16 \%$ ) of instructors from the school of Business, Engineering, Health, Humanity and Natural Science, and Pedagogy and Vocational Teachers Education) of instructor respondents are respectively not competent in ICT skills. The ICT competence level of the remaining instructor respondents is not known. As shown in Table4, instructor respondents in Adama Science and Technology University are somewhat competent in ICT skills (grand mean=2.57).

\subsection{Extent of Integration of ICT to Pedagogy/Teaching-learning and Ethics in Teaching- learning Practices}

Table 5shows that $135(66 \%)$ of instructor respondents empower students to purposefully select activities, applications and modes of communication, while 139(69\%) of respondents provide processing and presentation tools, similarly, 137(68\%) provide problem-solving challenges. On the other hand less number of the instructor respondents did not perform these activities. The remaining (less than 10\%) of the instructors did not decide whether these activities were done by them or not. As can be seen in Table5, the majority $177(87 \%)$ of respondents use information from online sources, and $169(84 \%)$ of respondents select and use learning objects to create learning activities and sequences and these activities were not performed by less than $10 \%$ of respondents. Similarly, $141(70 \%)$ of the respondents also engage students with virtual objects and worlds, whereas $21 \%$ of them did not engage students with virtual objects.

Table 5. Instructors' use of ICT in teaching for conceptual development

\begin{tabular}{|c|c|c|c|c|c|c|}
\hline \multirow{2}{*}{ Abbreviated items } & \multicolumn{2}{|c|}{ Disagree(1) } & \multicolumn{2}{|c|}{ Agree(2) } & \multicolumn{2}{|c|}{$\begin{array}{c}\text { Undecided } \\
\text { (3) }\end{array}$} \\
\cline { 2 - 7 } & $\mathrm{f}$ & $\%$ & $\mathrm{f}$ & $\%$ & $\mathrm{f}$ & $\%$ \\
\hline $\begin{array}{c}\text { Empower students to } \\
\text { purposefully select } \\
\text { activities, applications } \\
\text { and modes of } \\
\text { communication. }\end{array}$ & 49 & 24.5 & 135 & 66 & 19 & 9.5 \\
\hline $\begin{array}{c}\text { Use information from } \\
\text { online sources. }\end{array}$ & 18 & 9 & 177 & 87 & 8 & 3.5 \\
\hline $\begin{array}{c}\text { Select and use learning } \\
\text { objects to create learning } \\
\text { activities and sequences. }\end{array}$ & 15 & 7 & 169 & 84 & 19 & 9 \\
\hline $\begin{array}{c}\text { Provide processing and } \\
\text { presentation tools. }\end{array}$ & 47 & 23 & 139 & 69 & 17 & 8 \\
\hline $\begin{array}{c}\text { Provide problem-solving } \\
\text { challenges. }\end{array}$ & 53 & 26 & 137 & 68 & 13 & 6 \\
\hline $\begin{array}{c}\text { Engage students with } \\
\text { virtual objects and } \\
\text { worlds. }\end{array}$ & 43 & 21 & 141 & 70 & 19 & 9 \\
\hline
\end{tabular}


When interviewees were asked if they should use ICT for teaching-learning practices; almost all of the respondents agreed that it is important for the students to be exposed to ICT because students will learn new knowledge, attitudes and skills and it would make lessons to be more interesting. Others added by saying that ICT will make students to be competent as we are living in an information technology age.

In this regard, there are numerous benefits derived from the integration of ICT tools in enhancing quality education such as the ability for student to choose when to learn irrespective of geographical location without stress. Secondly, ICT also enable students to discover and explore new ideas or innovations from experts around the global world through the use of the common ICT available facilities. Thirdly, the existence of ICT into education system will enable delivery of teachers to students, monitoring of student progress and assessment can be done timely.

As can be seen in Table 6, the majority of $(67.5 \%)$ instructor respondents provide communication and collaboration tools, while $22 \%$ of instructor don't use this technique to facilitate leaning - environment. Similarly, $68.5 \%$ of the respondents also provide opportunities for students to be part of broader communities, whereas, $23 \%$ of the respondents don't provide this technique. As indicated in Table 6, the majority of instructor respondents use three other techniques (support student participation in online collaborative projects $(65 \%)$ which facilitate students leaning through TCT; make learning activities, information, courses and feedback available online anywhere-anytime $(63 \%)$, and support students using online resources to share with other students and experts $(64 \%))$. These show that even though more than halve of the respondents are facilitating students learning through ICT, there are instructors who don't use different techniques to facilitate students' use of ICT resources in their learning.

Table7, shows that Adama Science and Technology University instructor respondents are using ICT in preparing lectures and presentation (62\%); to communicate with others in the academic community assignments (72\%); to preparing assignments and exams (70\%); for preparing and reporting $\operatorname{grade}(70 \%)$; and for giving information and material to others $(70 \%)$. As can be seen in Table 7 , there are few teachers who don't use ICT in these instructional activities. Similarly, $67 \%$ of the instructor respondents use ICT for tracking progress record completion and achievement and giving feedback on students learning but $19 \%$ of the remaining respondents don't use ICT for this purpose. Whereas, equal number of respondents (30.5\%) don't' use ICT to do research and linking teaching with practical work instructional activity; but less number of the respondents don't have stand to use or not to use ICT in those instructional activities. As the same time, more than half of the respondents use for further practical activities, for doing research (58\%), linking teaching with practical work (53\%) and for aligning programs and resources with course frameworks (55\%).

Table 6. Instructors' use of ICT in building learning - environment

\begin{tabular}{|c|c|c|c|c|c|c|}
\hline \multirow{2}{*}{ Abbreviated items } & \multicolumn{2}{|c|}{ Disagree(1) } & \multicolumn{2}{|c|}{ Agree(2) } & \multicolumn{2}{|c|}{ Undecided(3) } \\
\hline & $\mathrm{f}$ & $\%$ & f & $\%$ & $\mathrm{f}$ & $\%$ \\
\hline $\begin{array}{l}\text { Provide communication and collaboration tools such as chat, } \\
\text { e-mail., messaging, discussion forums, online meetings and video } \\
\text { conferencing. }\end{array}$ & 45 & 22 & 136 & 67.5 & 22 & 10.5 \\
\hline $\begin{array}{l}\text { Provide opportunities for students to be part of broader } \\
\text { communities. }\end{array}$ & 47 & 23 & 138 & 68.5 & 22 & 10.5 \\
\hline Support student participation in online collaborative projects. & 55 & 27 & 130 & 64.5 & 18 & 8.5 \\
\hline $\begin{array}{l}\text { Make learning activities, information, courses and feedback } \\
\text { available online anywhere - anytime. }\end{array}$ & 59 & 29 & 127 & 63 & 17 & 8 \\
\hline $\begin{array}{l}\text { Support students using online resources to share with other } \\
\text { students and experts. }\end{array}$ & 57 & 28 & 129 & 64 & 17 & 8 \\
\hline
\end{tabular}


Table 7. Instructors' practices in using ICT in teaching - learning processes

\begin{tabular}{|c|c|c|c|c|c|c|c|}
\hline \multirow{2}{*}{ Abbreviated items } & \multicolumn{2}{|c|}{ Disagree $(1)$} & \multicolumn{2}{|c|}{ Agree(2) } & \multicolumn{2}{|c|}{ Undecided(3) } & \multirow{2}{*}{$\begin{array}{c}\text { Mea } \\
\mathrm{n}\end{array}$} \\
\hline & $\mathrm{f}$ & $\%$ & $\mathrm{f}$ & $\%$ & $\mathrm{f}$ & $\%$ & \\
\hline Preparing lectures and presentation & 59 & 29 & 125 & 62 & 19 & 9 & 1.80 \\
\hline Communicating with others in the academic community & 42 & 20.5 & 145 & 72 & 16 & 7.5 & 1.87 \\
\hline Preparing assignments and exams & 44 & 21.5 & 141 & 70 & 18 & 8.5 & 1.87 \\
\hline Doing research & 62 & 30.5 & 117 & 58 & 24 & 11.5 & 1.81 \\
\hline Preparing and reporting grade & 49 & 24 & 141 & 70 & 13 & 6 & 1.82 \\
\hline Giving feedback on students learning & 51 & 25 & 113 & 56 & 39 & 19 & 1.94 \\
\hline Track progress and record completion and achievement & 39 & 19 & 135 & 67 & 29 & 14 & 1.95 \\
\hline Linking teaching with practical work & 62 & 30.5 & 107 & 53 & 34 & 16.5 & 1.86 \\
\hline Align programs and resources with course frameworks & 52 & 25.5 & 111 & 55 & 40 & 19.5 & 1.94 \\
\hline Giving information and material to others & 24 & 11.5 & 141 & 70 & 38 & 18.5 & 2.07 \\
\hline Grand mean & & & & & & & 1.89 \\
\hline
\end{tabular}

As can be seen in Table 7, even though ICT is used in the sample schools of the university (grand mean, 1.89) instructors are not using ICT for instructional activities as expected at this level of education that is the percent of respondents who are using ICT for different activities is not as expected. When interviewed, the lecturers were asked: Have you had direct experience of planning and managing lessons with ICT in the classroom? Do you feel confident about helping your students work with ICT in classrooms? Such questions were not responded positively. According to the information that was gathered through observations, the general use of ICT integration into teaching-learning practice in Sample University is inadequate. The predominantly used computer technology software is the Word Processor, Internet and e-mail usage by most instructors. Basically, at the moment, there seem to be less ICT teaching-learning integration. Even though, ICT resources are mainly use for professional development purposes in this university. Instructors seem to view ICT learning as an added learning area rather than an integrated resource to be used within teaching and learning.

\subsection{Issues and Challenges (Trainings, Attitudes, Support, Materials and Classroom Conditions) Affecting the Use of ICT in Universities Teaching- Learning Process}

In order to address questions concerning challenges affecting the use of ICT in universities teaching- learning process different items were presented to instructors of the sample schools. The following tables present the data obtained through questionnaire.

As shown in Table 8, above sample instructor respondents from the school of Business (68.3\%), Health (65.6\%) and Humanity and Natural Science (68.8\%) had never taken training on ICT integration in to the teaching-learning practices. From the remaining respondents $26.8 \%$ in the school of Business, $18.8 \%$ in the school of Health, $25 \%$ in the school of Humanity and Natural Science had taken this training occasionally and less number of respondents in each school had often taken this training always. As it can be seen in items 2 and 5 even if the number of respondents in the School of Educational Science and Technology of Teachers Education, and schools of Engineering who had taken training on integration of ICT is greater than the other respondents still there are instructors who didn't taken the training at all. The instructors were asked: Have you ever received any ICT training? If yes, can you give details of this training? When asked if they feel that the training they received prepared them adequately for using ICT in their classroom. The first interviewee responded by saying that she still cannot use the computer well and she thinks of getting part time classes before she can proudly say, " I am computer literate", Other interviewees agreed that they are in a better position to use ICT for preparing mark lists and prepare worksheets for students but they were not sure whether they could use it for teaching students.

Most of the instructors in Adama Science and Technology University have never been exposed to ICT integration into teaching-learning training except for a few day orientations that was provided by 'the university. Only few instructors have undergone a professional training in the field of computer-based education through different higher education institutions. The number of instructors in need of retraining is very large. Instructors provided evidence of the necessity for another ICT training to promote professional development in integrating Information Communication Technology (ICT) into classroom teaching. The training that was provided by the Adama University for small number of instructors is viewed as being very important to the instructors who were interviewed as they claim that it gave them the basic computer skills. One instructor said, "It was for the first time that I use a computer". Indeed, it seemed to be for the first time that most instructors observed received ICT training, because some struggled to even move a mouse or use keyboard keys.

Instructors see a need to develop more confidence in using ICT as a necessary requirement to exploring more effective ways of using ICT for teaching and learning. As a result, their priorities are still for more basic computer skills and knowledge despite the fact that they have already received 
some basic ICT training. The evidence suggests that instructors are still in the early stages of ICT development. While they are interested in developing their skills and knowledge, many instructors still regard ICT as an extra learning area in their teaching, which is why they felt it was better if students had a computer period added in their timetable.

While instructors need to be aware of broad range of ICT software and resources, their training needs should relate to the technologies that are available to them on day-to-day basis. The above is stated because during the training observation, the Internet lesson unit was unclear to instructors as it was not live but stored on a computer. Albion (in Phelps, Graham \& Kerr, [25]) suggests that the professional development in ICT has to be an essential part of the instructor's career; it should be ongoing, intensive and well planned to be effective and sustainable. Reid (in Cabanatan, [8]) states that no matter how good the quality of the training is, if it is not related to the ICT resource available, it is 'likely to be seen by instructors as a waste of time and effort. It is important therefore that instructor training should be flexible enough in order for instructors to cope with ICT developments. It is clear, however that instructors needs have to be considered if training is to have the maximum impact (Seyoum, [28]).

Table 8. Instructors" extent of training on integration of ICT in to the teaching-learning process

\begin{tabular}{|c|c|c|c|c|c|c|c|}
\hline \multirow{2}{*}{ Schools } & \multicolumn{2}{|c|}{ Always (3) } & \multicolumn{2}{|c|}{ Occasionally(2) } & \multicolumn{2}{|c|}{ Never(1) } & \multirow{2}{*}{ Mean } \\
\hline & $\mathrm{f}$ & $\%$ & $\mathrm{f}$ & $\%$ & $\mathrm{f}$ & $\%$ & \\
\hline School of Business & 2 & 4.9 & 11 & 26.8 & 28 & 68.3 & 1.37 \\
\hline School of Engineering & 8 & 13 & 35 & 59.3 & 16 & 27.8 & 1.82 \\
\hline School of Health & 5 & 15.6 & 6 & 18.8 & 21 & 65.6 & 1.50 \\
\hline School of Humanity and Natural Science & 3 & 6.3 & 12 & 25 & 33 & 68.8 & 1.38 \\
\hline $\begin{array}{l}\text { School of Educational Science\& Technology of Teachers } \\
\text { Education }\end{array}$ & 2 & 8 & 16 & 64 & 7 & 28 & 1.80 \\
\hline Grand mean & & & & 57 & & & \\
\hline
\end{tabular}

Table 9. Instructors' attitude towards ICT integration into teaching-learning process

\begin{tabular}{|c|c|c|c|c|c|c|}
\hline \multirow{2}{*}{ Abbreviated items } & \multicolumn{2}{|c|}{ Disagree(1) } & \multicolumn{2}{|c|}{ Agree(2) } & \multicolumn{2}{|c|}{ Undecided(3) } \\
\hline & f & $\%$ & f & $\%$ & f & $\%$ \\
\hline I am interested to use ICT in teaching-learning process. & 42 & 20.5 & 146 & 72.5 & 15 & 7 \\
\hline I feel ICT training is appropriate to my teaching-learning & 18 & 8.5 & 176 & 87.5 & 9 & 4 \\
\hline $\begin{array}{l}\text { I feel I should develop my skills to keep up to date with developments in teaching- } \\
\text { learning integration. }\end{array}$ & 21 & 10 & 176 & 87.5 & 6 & 2.5 \\
\hline I need to develop my skills and knowledge of ICT. & 18 & 8.5 & 174 & 86.5 & 11 & 5 \\
\hline I am interested in teaching-learning process through ICT but I don't have access. & 52 & 25.5 & 125 & 62 & 26 & 12.5 \\
\hline I don't need to use ICT in my teaching-learning. & 164 & 81.5 & 27 & 13 & 12 & 5.5 \\
\hline I am interested but training doesn't seem to be available. & 45 & 22 & 137 & 68 & 21 & 10 \\
\hline I feel my knowledge and skills in ICT are adequate. & 137 & 68 & 48 & 23.5 & 18 & 8.5 \\
\hline I feel that I am ready to integrate ICT into the teaching-learning process. & 126 & 62.5 & 54 & 26.5 & 23 & 11 \\
\hline
\end{tabular}


As shown in Table 9, above the majority 146(72.5\%) of instructor respondents are interested to use ICT in teaching-learning process and $176(87.5 \%)$ of respondents feel that ICT training is appropriate to their teaching-learning and as they should develop skills to up to date with developments in teaching- learning integration. As it can be seen in Table 9, $174(86.5 \%)$ of the instructor respondents need to develop their skills and knowledge of ICT and interested in teaching-learning process through ICT; one of the interesting was164 (81.5\%) of respondents don't need to use ICT in their teaching-learning practices. Similarly, one of respondent said that "I don't have access and the training doesn't seem to be available to me". Further, 137(68\%) of the respondents also do not feel their knowledge and skills in ICT is adequate and not ready to integrate ICT into the teaching-learning process. Only few respondents feel that they have adequate knowledge and skills in ICT and are ready to integrate ICT into the teaching-learning process and the remaining instructors can't able to decide their position concerning those facts.

Table 10, above is about the respondents' opinion towards ICT. As shown in this Table, the majority $(89 \%)$ of the respondents have opinions to know more about ICT and only $11 \%$ of them have no opinions. However, more than half $(57.6 \%)$ of the respondents do not know the basics of ICT. About $58 \%$ of the respondents indicated as they use it effectively for themselves but not skillful to teach others. The remaining respondents $(41.9 \%)$ do not use it effectively for themselves and not skillful to teach others. As seen in item four of Table 10, the majority of the respondents consider that using ICT is not time consuming (80.8\%). However, more than $73 \%$ of the instructors believe in that ICT makes work easier, feel supported by their use of ICT (71.4\%) and respondents agree on the benefit of ICT for communication with colleagues (70.9\%).

Table 10. Instructors' opinions toward ICT

\begin{tabular}{|c|c|c|c|c|}
\hline \multirow{2}{*}{ Abbreviated items } & \multicolumn{2}{|c|}{ Yes } & \multicolumn{2}{c|}{ No } \\
\cline { 2 - 5 } & $\mathrm{f}$ & $\%$ & $\mathrm{f}$ & $\%$ \\
\hline I'd like to know more about ICT. & 181 & 89.1 & 22 & 11 \\
\hline I know the basics of ICT. & 86 & 42.3 & 117 & 57.6 \\
\hline $\begin{array}{c}\text { I use it effectively for myself but I } \\
\text { am not skillful to teach others. }\end{array}$ & 118 & 58.1 & 85 & 41.9 \\
\hline $\begin{array}{c}\text { I found that using ICT is time } \\
\text { consuming. }\end{array}$ & 39 & 19.2 & 164 & 80.8 \\
\hline It makes my work easier. & 149 & 73.4 & 54 & 26.6 \\
\hline I feel supported in my use of ICT. & 145 & 71.4 & 58 & 28.6 \\
\hline $\begin{array}{c}\text { It helps me communicate with } \\
\text { colleagues. }\end{array}$ & 144 & 70.9 & 59 & 29.0 \\
\hline
\end{tabular}

Table 11. Instructors' views on the integration of ICT into teaching-learning process

\begin{tabular}{|c|c|c|c|c|c|c|}
\hline \multirow{2}{*}{$\begin{array}{c}\text { Effective integration of ICT can transform teaching-learning by empowering } \\
\text { instructors to: }\end{array}$} & \multicolumn{2}{|c|}{ Disagree(1) } & \multicolumn{2}{|c|}{ Agree(2) } & \multicolumn{3}{|c|}{ Undecided(3) } \\
\cline { 2 - 7 } & $\mathrm{f}$ & $\%$ & $\mathrm{f}$ & $\%$ & $\mathrm{f}$ & $\%$ \\
\hline Focus on student-centred/ interactive learning & 31 & 15.0 & 160 & 79.5 & 12 & 5.5 \\
\hline Connect with student expectations, experiences and needs. & 30 & 14.5 & 165 & 82 & 8 & 3.5 \\
\hline Develop critical and ethical understandings of the value of the use of ICT. & 24 & 11.5 & 167 & 83.0 & 12 & 5.5 \\
\hline Ensure that use of ICT adds value to the intended learning. & 18 & 8.5 & 173 & 86.0 & 12 & 5.5 \\
\hline $\begin{array}{c}\text { Design learning programs that ensure the integrity of the learning area and } \\
\text { the inclusion of all students. }\end{array}$ & 25 & 12.0 & 162 & 80.5 & 16 & 7.5 \\
\hline $\begin{array}{c}\text { Scaffold learning using appropriate technologies, content, services and } \\
\text { environments. }\end{array}$ & 32 & 15.5 & 151 & 75.0 & 20 & 9.5 \\
\hline $\begin{array}{c}\text { Appraise the effectiveness, efficiencies and ethics of the use of ICT while } \\
\text { designing learning courses. }\end{array}$ & 27 & 13.0 & 161 & 80.0 & 15 & 7.0 \\
\hline Make connections with learning goals and prior knowledge. & 33 & 16.0 & 157 & 78.0 & 13 & 6.0 \\
\hline Understand the potential of ICT to support learning. & 26 & 12.5 & 165 & 82.0 & 12 & 5.5 \\
\hline
\end{tabular}

Table 12. Priority context for developing knowledge and skills in ICT resources processing

\begin{tabular}{|c|c|c|c|c|c|c|c|c|}
\hline \multirow{3}{*}{ Alternatives } & \multicolumn{8}{|c|}{ Ranking } \\
\hline & \multicolumn{2}{|c|}{$1^{\text {st }}$} & \multicolumn{2}{|c|}{$2^{\text {nd }}$} & \multicolumn{2}{|c|}{$3^{\text {rd }}$} & \multicolumn{2}{|c|}{$4^{\text {th }}$} \\
\hline & $f$ & $\%$ & $\mathrm{~F}$ & $\%$ & $f$ & $\%$ & $\mathrm{f}$ & $\%$ \\
\hline Professional development & 26 & 12.5 & 44 & 21.5 & 111 & 55.0 & 22 & 11.0 \\
\hline Classroom practice & 129 & 64.0 & 18 & 8.5 & 35 & 17.0 & 21 & 10.5 \\
\hline Personal use & 31 & 15.0 & 126 & 62.5 & 25 & 12.0 & 21 & 10.5 \\
\hline Administration & 15 & 7.0 & 22 & 10.5 & 40 & 19.5 & 126 & 63.0 \\
\hline
\end{tabular}


Table 13. Obstacles to do not use ICT resources in the teaching - leaning activities

\begin{tabular}{|c|c|c|c|c|c|c|c|c|c|c|c|c|}
\hline \multicolumn{13}{|c|}{ Ranking } \\
\hline \multirow{3}{*}{ Schools } & \multicolumn{2}{|c|}{$1^{\text {st }}$} & \multicolumn{2}{|c|}{$2^{\text {nd }}$} & \multicolumn{2}{|c|}{$3^{\text {rd }}$} & \multicolumn{2}{|c|}{$4^{\text {th }}$} & \multicolumn{2}{|c|}{$5^{\text {th }}$} & \multicolumn{2}{|c|}{$6^{\text {th }}$} \\
\hline & \multicolumn{2}{|c|}{$\begin{array}{c}\text { Lack of } \\
\text { skills }\end{array}$} & \multicolumn{2}{|c|}{$\begin{array}{l}\text { Lack of } \\
\text { training }\end{array}$} & \multicolumn{2}{|c|}{$\begin{array}{l}\text { Lack of } \\
\text { support }\end{array}$} & \multicolumn{2}{|c|}{$\begin{array}{c}\text { Not } \\
\text { accessible }\end{array}$} & \multicolumn{2}{|c|}{$\begin{array}{c}\text { Lack of } \\
\text { confidence }\end{array}$} & \multicolumn{2}{|c|}{$\begin{array}{l}\text { Lack of } \\
\text { time }\end{array}$} \\
\hline & $\mathrm{f}$ & $\%$ & $\mathrm{f}$ & $\%$ & $\mathrm{~F}$ & $\%$ & $\mathrm{f}$ & $\%$ & $\mathrm{f}$ & $\%$ & $\mathrm{f}$ & $\%$ \\
\hline School of Business & 13 & 31.7 & 9 & 22 & 8 & 19.5 & 3 & 7.3 & 2 & 4.9 & 6 & 14.6 \\
\hline School of Engineering & 15 & 25.9 & 12 & 20.9 & 11 & 18.5 & 8 & 14.8 & 9 & 16.7 & 2 & 3.7 \\
\hline School of Health & 10 & 31.2 & 12 & 43.8 & 6 & 18.8 & 4 & 12.5 & - & - & - & - \\
\hline $\begin{array}{l}\text { School of Humanity and Natural } \\
\text { Science }\end{array}$ & 13 & 27.1 & 15 & 31.3 & 11 & 22.9 & 3 & 6.3 & 6 & 12.5 & - & - \\
\hline School of ES \&TTE & 7 & 28 & 11 & 44 & 5 & 20 & 2 & 8 & - & - & - & - \\
\hline
\end{tabular}

Table 11, above is about instructors' views on their roles for effective integration of ICT into teaching-learning practices. As shown in this Table, the majority of the respondents replied that effective integration of ICT can transform teaching-learning by empowering instructors to: focus on student-centred/interactive learning(79.5\%); connect with student expectations, experiences and needs $(82 \%)$; develop critical and ethical understandings of the value of the use of ICT $(83 \%)$; ensure that use of ICT adds value to the intended learning $(86 \%)$; scaffold learning using appropriate technologies, content, services and environments $(75 \%)$; appraise the effectiveness, efficiencies and ethics of the use of ICT while designing learning courses $(80 \%)$; to make connections with learning goals and prior knowledge $(78 \%)$; and understand the potential of ICT to support learning $(82 \%)$. Less number of these instructors didn't believe on empowering instructors to the above activities for effective integration of ICT to transform teaching-learning practices.

As shown in Table 12, above the majority instructor respondents rank classroom practice first (64\%), personal use second $(62.5 \%)$, professional development third $(55 \%)$, and administration fourth (63\%) as their priority context for developing knowledge and skills in ICT resources processing.

As can be seen in Table 13, above the instructor respondents ranked the obstacles not use of computer sources in their teaching-learning activities were presented. Accordingly, lack of computer skills is the first $(31.7 \%$ \& $25.9 \%)$ most problem for instructor respondents of the School of Business and school of Engineering respectively. While, $(43.8 \%, 31.3 \% \& 44 \%)$ of instructor respondents in the School of Health, Humanity and Natural Science, and School of Educational Science and Technology of Teachers Education in each sample schools responded that lack of training is the second most obstacles to use computer resource respectively. As indicated in column of the above Table lack of support is the third problem almost for all instructor respondents in the sample schools. Lack of computer resources access, lack of instructor's confidence and lack of time to use computer resources results vary from school to school.

\section{Discussions}

In this part of the study, an attempt is made to explain the results of the study with reference to the basic questions formulated understatement of the problem. The major themes of the discussion are: Instructors' knowledge and skills of basic ICT resources (Internet, E-mail, word processing, databases, spread sheets, digital scanners, and education software package and computer printer); extent of Integration of ICT into teaching-learning practices and issues and challenges (trainings, attitudes, support, materials and classroom conditions) affecting the use of ICT in universities teaching- learning process.

\subsection{Information Arising from Questionnaires, Observations and Interviews}

Informant were asked questions aimed at determining how instructors (they) use ICT resources for integrating into learning and teaching; to what extent they are trained for using ICTs for pedagogy/teaching-learning. The questionnaire generated the following information concerning instructors:

- Instructor access to ICT resources at Adama Science and Technology University showed to be fairly accessible.

- Most informants showed to have never used ICT resources (except Word Processor, Computer printer, Internet and e-mail usage) for integration into teaching-learning purposes, rather than administration.

- It was discovered that almost all of instructors used computers for Word Processor in their homes and most ICT resources, while like the digital cameras, database, digital scanners, spreadsheets and educational software 
package were almost never used. It was found that the majority of instructors use ICT resources like Internet, e-mail, word-processing and the printer for administrative purpose.

- The reasons given by most respondent instructors for not using the above stated ICT resources include the following: lack of skills, training, pedagogical support, technical support, time, instructors reserved attitudes and not accessible when needed (The above reasons reveal that most instructors in this sample university appear not to be familiar with some of the ICT resources itself. The researcher concludes that this is because most of the above stated ICT resources are available in the university store and computer laboratory as well in office of supportive staff).

- There was an increased level of interest on the majority of instructors who wish to know more about ICT in order to develop their skills and knowledge in ICT and how they can integrate ICT for pedagogy/ teaching-learning.

- A very low level of ICT resources competence was discovered in most instructors, which was shown by the non-utilization of the ICT resources laboratory for learning in this university.

- Most instructors agreed that they needed to develop their ICT skills and knowledge for the classroom practice but training seemed not to be available.

- Some instructors partially agreed that they are better at using computers for teaching after completing the computer training by them.

- A majority of the instructors agreed with the following statements:

○ to keep up-to-date with ICT integration.

○ to learn more about using ICT for teaching and learning.

○ to improve ICT skills and knowledge for the students' benefit.

- Respondents were asked to describe the priorities for developing their ICT skills and knowledge in each of the four contexts. Hence, they ranked classroom practice, personal use, and professional development and administration purposes respectively. Their responses were similar, as most instructors placed the majority of their ICT training priority in the context of the classroom practice.

The following information was learned during the interviews with instructors:

After the collection of data through the interviews, there were some concerns and problems that the instructors had (at the university where the study took place) with integrating ICT for pedagogy/teaching- learning. Most of the concerns were grouped into the following findings: The need for training to use ICT for teaching- learning; Instructors' preparedness to integrate ICT and Attitude towards ICT integration. The above findings and instructor concerns will now be discussed..

\subsection{A Need for Training to Use ICT for Teaching and Learning}

The number of instructors in need of retraining is very large. Instructors provided evidence of the necessity for another ICT training to promote professional development in integrating Information Communication Technology (ICT) into classroom teaching. The training that was provided by the Adama University for small number of instructors is viewed as being very important to the instructors who were interviewed as they claim that it gave them the basic computer skills. One instructor said, "It was for the first time that I use a computer". Indeed, it seemed to be for the first time that most instructors observed received ICT training, because some struggled to even move a mouse or use keyboard keys.

Instructors see a need to develop more confidence in using ICT as a necessary requirement to exploring more effective ways of using ICT for teaching and learning. As a result, their priorities are still for more basic computer skills and knowledge despite the fact that they have already received some basic ICT training. The evidence suggests that instructors are still in the early stages of ICT development. While they are interested in developing their skills and knowledge, many instructors still regard ICT as an extra learning area in their teaching, which is why they felt it was better if students had a computer period added in their timetable.

While instructors need to be aware of broad range of ICT software and resources, their training needs should relate to the technologies that are available to them on day-to-day basis. The above is stated because during the training observation, the Internet lesson unit was unclear to instructors as it was not live but stored on a computer. Reid as cited in Gibson [13] states that no matter how good the quality of the training is, if it is not related to the ICT resource available, it is 'likely to be seen by instructors as a waste of time and effort. It is important therefore that instructor training should be flexible enough in order for instructors to cope with ICT developments. It is clear, however that instructors needs have to be considered if training is to have the maximum impact Selwyn, [27].

\subsection{Instructors' Preparedness to Integrate ICT into Teaching and Learning}

Instructor's visions for and the beliefs about working with ICT are an important influence on the successful application of ICT in education Albion cited in Phelps, Graham and Kerr, [25]. According to the questionnaire responses and the interview results, it is clear that instructor's knowledge and ICT skills are in short supply. Therefore the use of ICT should be improved and the focus should be on practical skills in the usage of ICT resources.

According to the guidelines given to the university by the Ministry of Capacity Building, instructors are challenged to 
integrate ICT for teaching and learning. Instructors are to teach with ICT for a given periods in each learning area per term MoE, [22]. They will have to use ICT to design an activity that students can learn from. This responsibility seems to be very difficult for instructors to deal with before mastering the basic computer literacy skills and showing confidence in the general use of ICT. In the university where this study is conducted, some instructors cannot use the computer for personal and administrative activities, let alone using it to teach students. Some rely on others to assist them in some administrative tasks like the spreadsheet for compiling mark lists, yet many instructors are required to teach without computers in every term.

Phelps, Graham and Kerr [25] suggest that the professional development in ICT has to be an essential part of the instructor's career; it should be ongoing, intensive and well planned to be effective and sustainable. Most interviewees felt that there should be some sharing of experiences and discussions about their readiness to use ICT for learning so that instructors receive support in keeping up to date with ICT developments.

\subsection{Attitude towards ICT Integration}

Seyoum, [28] states that universities that have good ICT resources and utilize them well have better standards than universities where good ICT resources were not well used. The use of ICT resources by university-instructors is still very rare and very few instructors have their students use ICT resources frequently Seyoum, [28].

Although policy-makers have clearly given statements about encouraging the use of ICT in universities, the use of ICT resources in this university is inadequate. The research findings in this university show that instructors are currently not using ICT resources available at the university teaching and learning. There is currently no professional development available for instructors. Many instructors are overwhelmed by the mandate to integrate ICT in every learning area and in each department. Adama university authorities should support and encourage instructors, as they get ready to integrate ICT in a meaningful and challenging way across the courses in teaching and learning process.

The following information will give a description from the interview questions and responses of how ICT was or is being currently utilized in Sample University.

The interviewees were asked exactly to explain how they used ICT in their classroom. In response, they said many students did not have access to ICT and the only time that these instructors used a computer was when they typed assessment activities for students.

When asked if they feel that the training they received prepared them adequately for using ICT in their classroom. The first interviewee responded by saying that she still cannot use the computer well and she thinks of getting part time classes before she can proudly say, " I am computer literate", Other interviewees agreed that they are in a better position to use ICT for preparing mark lists and prepare worksheets for students but they were not sure whether they could use it for teaching students.

\subsection{Using ICT Resources for Teaching and Learning at the Sample University}

When interviewees were asked, if they should use ICT for teaching and learning; all the respondents agreed that it is important for the students to be exposed to ICT because students will learn new knowledge, attitudes and skills and it would make lessons to be more interesting. Others added by saying that ICT will make students to be competent as we are living in an information technology age.

The question asked was whether teaching has changed since the instructors have been using ICT. The responses were that they still teach the same way as they did before being introduced to ICT as they don't use ICT for learning but only for worksheets preparation and creating learning area mark lists. Some responded by saying that their teaching could change if all students can have an access to a computer at the same time because at the moment less number of computer are available and some classes have more than 50 students.

When asked how students responded to instructors using ICT in class. The instructors' responses were: "My students haven't been taught using ICT, I haven't used ICT for teaching but I think my students can be excited, as they seem to love computers".

A lack of confidence in the instructor's computer skills appears to be a barrier to ICT integration. Although most instructors are interested in developing their ICT skills, it is important that they use those skills for pedagogy/teaching-learning integration. ICT need to be presented in a manner that course materials can be developed and delivered rather than as a separate unit Reid in Cabanatan, [8].

Reluctance to use ICT was more evident to foundation phase instructors; perhaps it is because instructors in this phase lacked the support on how foundation phase students are to be taught with computers. One foundation phase interviewee stated" I think ICT would make a lesson more interesting".

However most instructors had very firm ideas of how they would like to apply ICT in the classroom, they felt they could be held back by the lack of technical skills and confidence. This lack of confidence may be from the fact that instructors appeared to be less likely to be using ICT for their own professional development, personal use or administration purposes, of which practicing ICT skills might reinforce skills on a regular basis.

The main ICT resources that are used more frequently are word processing followed by spreadsheets for compiling learning area mark lists. It appeared that the majority of instructors are still in the early stages of ICT development, what would be referred to as the" entry" or " adoption" according to the National Standards for ICT in a Ethiopian context MoE, [22]. The use of ICT in this university is 
relatively low and focused on a fairly narrow range of ICT resources. There is a very little use of the Internet and the World Wide Web (WWW) by instructors, despite the fact that the university has an access to the Internet. The findings reveal that most instructors in this university see ICT as an extra learning area rather than an integrated resource within teaching and learning. Many instructors were still concerned with teaching ICT skills rather than teaching with ICT.

Instructors who were interviewed were generally positive and wanted to develop their ICT skills and knowledge for integration. These instructors had basic ICT skills but they felt that they are not yet competent to integrate ICT for pedagogy/teaching-learning. Instructors were asked what their barriers of not using ICT for teaching and learning. The interviewees responded by saying that the appropriate training and an ongoing support were not received from the ICT coordinators. It was therefore clear that these two areas of development (training and support) needed to be addressed for the expansion of instructors' skills and knowledge for ICT integration

\subsection{Training for ICT Integration}

Most instructors stated that ICT training did not meet their needs for ICT integration. They claim that the training was not sufficiently relevant for ICT integration but it was mainly aimed at giving those basic ICT skills (of which they say they needed those skills). Most respondents expressed a need for more training in ICT skills and knowledge across all four contexts, that is, classroom practice, professional development, personal use and administration purposes but most particularly in relation to the use of ICT in the classroom practice. Interview comments mainly revealed a need for more training in the area of ICT pedagogy/teaching-learning integration.

When instructors were asked if there were needs that they required to enhance their ICT integration, they identified the following: Training that is relevant for the classroom use; More practical examples of ICT integration lessons; Individual attention during ICT training; Opportunities to work and share ideas as a group regarding ICT integration and More support from ICT coordinators. The above are the needs that instructors require to enhance their ICT pedagogy/teaching-learning integration.

\section{Summary, Conclusions and Recommendations}

The previous chapter, chapter 3, presented the results and discussion of the empirical investigation. In this chapter, conclusions in line with the major findings and recommendations of the study are discussed. Finally, limitations of the research project are highlighted.

\subsection{Summary}

The main purpose of this study was to explore the integration of pedagogy/teaching-learning, ethics and Information Communication Technology (ICT) and surveying the issues and challenges affecting its implementation in Adama University.

In order to meet these purposes the following three basic questions were set:

1. What ICT resources (Internet, E-mail, word processing, databases, spread sheets, digital scanners, and education software package and computer printer) knowledge, attitudes and skills do the selected instructors have?

2. To what extent instructors integrate ICT to pedagogy/teaching-learning and ethics in instructional process?

3. What issues and challenges (materials, trainings, attitudes, support, and classroom conditions) affect the use of ICT in universities teaching- learning process?

To find solutions for these basic questions, study was conducted on five schools in Adama Science and Technology University. The data were collected from 203 respondents. The data were gathered mainly through questionnaire, interview and observation. The data obtained were analysed using percentages and means. Based on the analysis of the data collected through various instruments, the following summary was obtained from the study:

This study was directed towards determining the extent of the instructors' readiness to integrate ICT for teachinglearning in a selected Science and Technology University in Adama. It uncovered the aim and the importance of the use of ICT in education. Instructors gave their views, needs and concerns of how important ICT support and training is towards understanding ICT integration.

Further, this study attempts to answer questions on the roles of ICTs in education, existing promises, limitations and the challenges of its integration in education systems. Information communication technologies are influencing all aspects of life including education. They are promoting changes in working conditions, handling and exchanging of information, teaching-learning process and so on. One area in which the impacts of ICT is significant, is education. ICTs are making major differences in the teaching approaches and the ways students are learning. ICT-enhanced learning environment facilitates active, collaborative, creative, integrative, and evaluative learning as an advantage over the traditional method. In other words, ICT is becoming more appropriate in the realization and implementation of the emerging pedagogy of constructivism that gives greater responsibility of learning for students. Several surveys are showing that ICT use in education systems of developed nations has comparatively advanced than ICT use in education systems of developing nations.

In addition, the major promises of ICTs use in education systems of Ethiopian University focus on training teachers in new skills and introducing innovative pedagogies into the 
classrooms, investing on ICT infrastructure for universities and creating networks among universities, improving overall standard of education by reducing the gap in quality of education between universities, initiation of smart university with objectives to foster self-paced, self-assessed, and self-directed learning through the applications of ICTs, and developing ICT policy for education and training. On the other hand, this study discusses the major challenges of ICT use in education as instructor related, student related, and technology related. In addition, the key challenges of ICTs integration into education systems discussed relate to policy, planning, infrastructure, learning content and language, capacity building and financing.

What will be the way forward then? There is a consensus that the development of any country depends upon the quality of education programs offered to citizens. ICTs, despite their known limitations, are believed to be beneficial in this regard. The computer and the internet are especially useful to enhance student engagement in learning and positively impact student performance and achievement.

ICT integration can have a positive impact in teaching and learning process, which takes place in the teaching and learning situation. It is not the ICT itself, but the approach in which it is used that makes a worthy or a worthless resource. The instructors continues to be the mediator in the teaching and learning situation, thus it is imperative for instructors to be prepared in order to make ICT resources to be functional in the university.

It follows that it is very important that ICT instructor training should be relevant to the integration of ICT for teaching and learning rather than just giving instructors computer knowledge and skills. To help instructors overcome the pressures of seeing ICT as an additional burden, and encourage greater integration of ICT, it will be important that future ICT instructor training focus on ICT integration skills and knowledge. It is important that instructors are able to relate the ICT training they are offered to their existing goals and objectives. It is further important that there is an ongoing provision for instructor development to enable instructors to move-on with ICT integration once they have acquired the basic computer skills, which many in this selected university feel they need. Future ICT instructor training and development opportunities should focus on the benefits of instructors and not simply how to use computers, this can be done through broadening the awareness of a wide range of ICT resources with less emphasis on word-processing and spreadsheets, and more on resources which are currently not in use such as the Internet, e-mail, multimedia software.

To date, ICT instructor training regarding ICT integration for teaching and learning has been short of what is required, as it has not sufficiently provided the instructors with the required skills of integrating ICT for learning. It is evident that what delays ICT integration in the selected university is the lack of appropriate ICT integration training, lack of administrative support, instructors' confidence in using ICT, reluctance towards the use of ICT and the roles to be played by instructors in ICT integration.

Moreover, ICT should be seen as a tool for life-long learning for instructors as well as their students. It should be the aim of the instructors in a selected university to teach students with computers and to allow students to have access to computers and software suitable for them, e.g. Microsoft PowerPoint and the Internet. Instructors should focus on using the resources available on the computer laboratory and store to make ICT integration successful at a selected university. Instructors have to be encouraged to make decisions about their own ICT development needs on an ongoing basis. This will ensure more involvement and integration of ICT within the teaching and learning process.

Opportunities for professional development have to be continuously available for instructors to continue improving their computer, knowledge, skills and attitudes. Professional development should not only provide instructors with perspective on the operational use of ICT, i.e. the use computer hardware and software, but also focus on the skills involving the use of computer-based tools to support teaching and learning. Instructors would therefore need to understand the rationale for integrating compoture-based tools into teaching and learning environments.

ICT should be a compulsory course in the universities for instructors so that instructor can begin their teaching career as experts in the ICT field. University vice presidents, school deans and concerned bodies should offer mandatory workshops and courses to help instructors gain the knowledge and skills they require to teach their students with ICT resources. This is a better way to make sure that instructors continue to learn the latest ICT information. Instructors should not only attend workshops, but they should also come back and share the information as a team. Thus, instructors will have time to reflect on aims, instructional methods and assessment as they design ICT interactive lessons for their students..

\subsection{Conclusions}

In conclusion, the researcher would like to point to the words of Wood cited in Anderson \& vanWeert, [2], stating that to spend on ICT in universities does not necessarily guarantee improved teaching and learning environments and improved ICT student outcomes. Education is a long-term growth and integrating ICT in education is new to most instructors, therefore it can take time for instructors to learn and apply ICT into teaching and learning. It is a responsibility that is ever-changing due to technological advance and it cannot be completed in a short period of time.

It is very clear that instructors will not get much scope in order to integrate ICT in curriculum or the teaching-learning process. In the university at the sample university level, the ICT education scenario is struggling with the following problems:

- Only at the awareness development level are objectives being achieved, but higher order thinking skills regarding the use of ICT tend not to be occurring. 
- Technology, pedagogy and content area integration is a rare feature. All components are dealt with separately which creates confusion for students.

- Time duration of the courses related to ICT education is too short to develop knowledge and necessary skills among students to achieve higher order thinking skills.

- There is a lack of availability of proper infrastructural facilities at most of the schools/faculties in integrating ICT into teaching-learning process.

- There is a mismatch between available hardware and software to develop required learning resources.

- Support from technical staff for maintenance is limited.

The study has examined the relationships among instructors' levels of technology use and a number of key factors including years of experience, ease-of use, and access to resources. Achieving meaningful technology use is a slow process that is influenced by many factors. When educators and researchers look for ways to help instructors use technology effectively, it may be important to look at what they have (in terms of equipment) in addition to what they do not have (in terms of positive technology inclinations). Understanding instructors' visions for technology use and their beliefs about teaching and learning may be necessary if we want to initiate an adoption of modern technology interventions in teaching pedagogy.

In areas with a continuous change of technological content, as with information and communication technologies, the problem is the difficulty in selecting and organizing the knowledge to be taught. In terms of technical support, experts, and course materials ICT-based education system is expected to enhance its capability to satisfy the user groups. On the one hand, new knowledge has to be added to the curriculum constantly, and at the same time any other knowledge becomes obsolete. On the other hand, content has to be organized and ordered, relating every concept to others, which is not a trivial task because of their number and how often they change.

Many exciting applications of information technology in classrooms validate that new technology based models of teaching and learning have the power to dramatically improve educational outcomes. But, classroom computers that are acquired as panaceas end up as doorstops. Unless other simultaneous innovations in pedagogy, curriculum, assessment, and school organization are coupled to the usage of instructional technology, the time and effort expended on implementing these devices produces few improvements in educational outcomes- and reinforces many educators' cynicism about fads based on magical machines. To further the study, it is imperative to further research into whether instructors who use technology are smartly predisposed to democratic, collaborative, problem based pedagogy, or does technology bring these behaviors into the classroom? Does improved student learning occur only when technology is introduced along with different teaching practices? What teaching practices are best suited to maximizing the potential of technology to improve student learning?

\subsection{Recommendations}

The ICT enhancement of the integration of ICT into teaching-learning practice/quality education discovered in both literature and findings regarding among Ethiopian universities requires that the following recommendations:

- The role of the deans, department heads, ICT leaders/coordinators and instructors in the ICT integration into teaching-learning and the utilisation of the ICT resources should be specified.

- The positive and the negative impact that ICT integration into teaching-learning in the sample university need attention.

- The type of ICT instructors training that can be offered in order to equip instructors with all the necessary skills for ICT integration.

- There should be follow up mechanisms of ICT integration in this university;

- Sample University should offer ICT integration training, given that all instructors should be able to integrate ICT for pedagogy/ teaching-learning;

- Further research can be conducted regarding instructors support (related to instructional process \& ICT integration) received from the School of Pedagogy and Vocational Teachers' Education with collaboration of ICT coordinators.

\section{REFERENCES}

[1] Akbulut, Y., Kesim, M., \& Odabasi, F. (2007). Construct Validation of ICT Indicators Measurement Scale (ICTIMS). [Electronic version]. International Journal of Education and Development using Information and Communication Technology, 3(3), 1 -17. Accessed on December 19, 2011:h Up:1lij edi ct.dec. uwi. edullviewarti cI e. ph p ?id=359\&1 ayou $\mathrm{t}=\mathrm{h} \mathrm{tml}$.

[2] Anderson, J and VanWeert, T. (Eds) (2002). Information and Communication Technology in Education: A Curriculum for Schools and Programme of Teacher Development. UNESCO, Paris.

[3] Asan, A. (2003). Computer Technology Awareness by Elementary School Teachers: A Case StUdy from Turkey. [Electronic version]. Journal of Information Technology Education, 2(2003), 153-164. Accessed on December 9, 2011: http://www.jite.org/documentslVoI2lv2p153-164-1 09.pdf .

[4] Barret, A M, (2009), The Education Millennium Development Goals Beyond 2015, Prospects for Quality and Learners, Edqual Working Paper No. 13, University of Bristol

[5] Becta ICT Research. (2005). The Becta Review 2005. Evidence on the Progress of ICT in Education. Accessed on December 19, 2011: http://www.becta.org.uk/page documentslresearch/becta review feb05.p:If 
[6] Becta ICT Research. (2006). The Becta Review 2006. Evidence on the Progress of ICT in Education. Accessed on December 19, 2011: http://becta.org . uk/corporate/publi cations/docum en tsIThe Becta Review 2006.pdf .

[7] Betts, S., (2003). Does the use of ICT affect quality in learning science at Key Stage 3? Studies in Teaching and Learning, pp. 9-17.

[8] Cabanatan, P. (2003). Integrating Pedagogy and Technology: The SEAMEO INNOTECH Experience Presentation to Experts' Meeting on Teachers/Facilitators Training in Technology- Pedagogy Integration, Bangkok, Thailand. June $18-20$.

[9] Carlson, S., \& Gadio, C. T. (2002). Teacher Professional Development in the Use of Technology. Accessed on December 19, 2011: http://www.schoolnetafrica.netlfi leadm in/resou rces/T each er Professi on al Developm e nt In the use of Technology.pdf.

[10] Creswell, J.W.(2009). Research design: A qualitative, quantitative, and mixed method approaches .Third Edition. Sage Publications. Inc.

[11] Cox, M.J., (2000). Information and communication technologies: Their role and value for science education. In: Good practice in science teaching - what research has tosay (Eds, Monk, M. and Osborne, J.). Open University Press. Milton Keynes.

[12] Francis, H. A, \& Ezeife, A N. (2007). Integrating Information and Communication Technology into the School Curriculum: A Case for Professional Development Models. Accessed on December 19, 2011: http://www.asstudents.unco.edu/students/AE-Extra/2007/4/E zeife.html

[13] Gibson, I. W. (2002). Technology, Pedagogy and Education. [Electronic version). Journal of Information for Teacher Education, 11(3), 315-334. Accessed on December 19, 2011: http://dx.doi.org/1 0.1080/14759390200200140

[14] Hare, H. (2007).ICT in Education in Ethiopia: SURVEY OF ICT AND EDUCATION IN AFRICA: Ethiopia Country Report, Accessed on May 23, 2011: http:// www.infodev.org.

[15] Jamieson-Proctor, R. M., Burnett, P. C., Finger, G., \& Watson, G. (2006). ICT Integration and Teachers' Confidence in Using ICT for Teaching and Learning in Queensland State Schools. [Electronic version). Australasian Journal of Educational Technology, 22(4), 511-530. Accessed on May 19, 2011: h ttp:/ $f v \cdot 1 W W$. asci Ii te .org. auf aj etl aj et $22 / \mathrm{j}$ am iesonproctor. $\mathrm{h} \mathrm{tml}$

[16] Kalake, M. (2007). Factors Enabling and Constraining ICT Implementation in schools: A Multiple Case Study of Three Secondary Schools in Lesotho. Rhodes University.

[17] Kovalchick, A., \& Dawson, K. (2004). Education and Technology: An Encyclopedia. California: ABC-CLIO.

[18] Kozma, R. B. (2008). 'Comparative analysis of policies for ICT in education. Center forTechnology in Learning', SRI International (to appear in the International Handbook onInformation Technology in Education).

[19] McCain, 1. D. E., \& Jukes, I. (2001). Windows of the Future. California: Corwin Press. McMillan, J. H., Schumacher, S. (2001). Research in Education. A Conceptual Introduction (5th ed.). New York: Longman.
[20] McRobb, S., Jefferies, P., Stahl, B. C. (2007). Exploring the relationship between pedagogy, ethics and technology: building a framework for strategy development. Technology, Pedagogy \& Education 16, 1, 111-126. DOI $=10.1080 / 14759390601168122$

[21] Ministry of Education[MoE]. (2002). The education and training policy and its implementation. Addis Ababa : Ministry of Education.

[22] Ministry of Capacity Building (2006).ICT in Education Implementation Strategy and Action Plan. National ICT4D Action Plan for Ethiopia. Accessed on May 23, 2011:http://www.estc.gov.et/ICT\%20policy.htm (Accesse on July 28, 2009).

[23] Parker, R. E., Bianchi, A., \& Cheah, T. Y. (2008). Perceptions of Instructional Technology: Factors of Influence and Anticipated Consequences. Educational Technology \& Society, 11 (2), 274-293.

[24] Pelgrum, W. J. (2007). IEA SITES International Report: School Conditions for Pedagogy and ICT: International Association for the Evaluation of Educational Achievement.

[25] Phelps, R., Graham, A., \& Kerr, B. (2004). Teachers and ICT: Exploring a Metacognitive Approach to Professional Development. [Electronic version]. Australasian Journal of Educational Technology, 20::1), 49-68. Accessed on March28,

2011:Up:!/www.ascilite.org.au/ajetlajet20/phelps.html.

[26] Rodrigues, S. (2005b). A Model of Teacher Professional Development. The Partnership in the Primary Science Project. New York: Nova Science Publishers

[27] Selwyn, N. (2002). Telling Tales on Technology: Qualitative Studies of Technology and Education. London: Ashgate Publishing Limited.

[28] Seyoum, A. F. (2004). Key Issues in the Implementing and Integration of ICT in Education System of the Developing Countries. Accessed on September 12, 2011:http://edu . etlsession $\quad \% 201 \quad \mathrm{~V} \quad$ fullpapers/Key\%20Challen qes\%20fators \%20i mpl em en tat ion Abebe\%20Feleke.!Xlf

[29] Thorburn, D. (2004). Technology Integration and Educational Change: Is it Possible? Accessed on August 20, 2011:from http://www.usask.caleducation/coursework/802papers/thorb urn/index.htm.UNESCO Information Programmes and Services. 2003. Teacher Training on ICT in Education inAsia and the Pacific: Overview from Selected Countries. UNESCO, Bangkok.

[30] UNESCO. (2002). Using ICT for Quality Teaching, Learning, and Effective Management: Report of the Seventh UNESCO-ACEID International Conference on Education (Bangkok, Thailand,11-14 December 2001). UNESCO, Bangkok.

[31] Vallance, M. (2008). Beyond Policy: Strategic Actions to Support ICT Integration in Japanese Schools. [Electronic version]. Australasian Journal of Educational Technology, 24(3), 275-293. Accessed on July 23, 2011:http://www.ascilite.org.au/aj et! aj et24/vall ance. pdf .

[32] Walsh, K. (2002). ICTs about Learning: School Leadership and the Effective Integration of Information and Communications Technology. Accessed on July 13, 2011: http://www . ncsl. org. uk/medi a/1 DO/C D/icts-about -Iearni ng. pdf . 
[33] Wang, Q., \& Woo, H. L. (2007). Systematic Planning for ICT Integration in Topic Learning. [Electronic version] Educational Technology and Society, 10(1), 148-156. Accessed on July 13, 2011: http://www.ifets.info/journals/1 0 1/14.lxlf.
[34] Zhu, Z. (2003). Teacher Training in Technology-Pedagogy Integration: A Concept Paper from China. Presentation to Experts' Meeting on Teachers/Facilitators Training in Technology-Pedagogy Integration, Bangkok, Thailand. June 18-20. 